\title{
A fehérjék táplálkozás-élettani hatása, szerepiik a sporttáplálkozásban
}

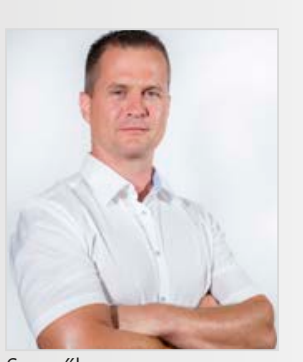

Szerzők:

Fritz Péter

Dr. habil.

Munkahelye:

Ferencvárosi Torna Klub

Levelezési címe:

1101, Budapest,

Vajda Péter utca 48.

E-mail címe

pritz@hotmail.hu

Tudományos tevékenysége:

doktori iskolában témavezetố

Főbb kutatási területei:

sporttáplálkozás, rekreáció

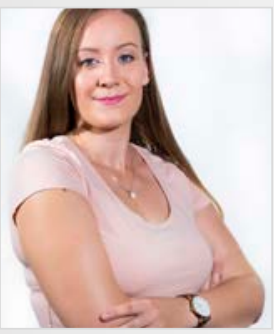

Mészáros Nikoletta

E-mail címe: nikolettadiet@ gmail.com

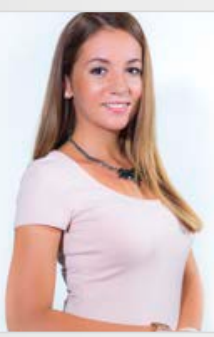

Ignits Dóra

E-mail címe:

dori.ignits@gmail.com

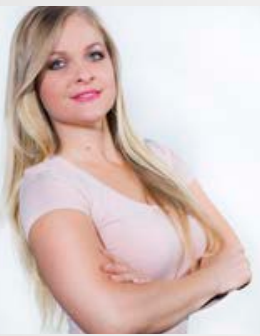

Katona Sára

E-mail címe: sarahann008@ gmail.com

\section{The nutritional and physiological effect of proteins, their influences on sports nutrition}

A Recreation magazin új rovattal bővül, melynek fő témája a sporttáplálkozás. A rovat célja, hogy az olvasó átfogó képet kapjon a sportolók táplálkozásával kapcsolatos aktuális tudományos ajánlásokról.

Az egyes lapszámokban áttekintjük a makrotápanyagok szerepét a sportban. Többek között választ kaphat az olvasó arra, hogy miért fokozott a fehérjeigénye egy sportolónak, a testösszetétel-változtatásnak milyen táplálkozási vonatkozásai vannak, melyek a legfontosabb fehérjeforrások, illetve hogy miért szükséges étrend-kiegészítőket alkalmazni sportolóknál, és tisztázzuk ezek használatával kapcsolatos tévhiteket is. A későbbiekben a zsírok és szénhidrátok testmozgásban betöltött szerepét is szeretnénk ismertetni.

\section{ÖSSZEFOGLALÁS}

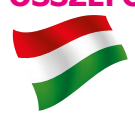

A fehérjék hosszú láncú aminosavakból felépülő makromolekulák. A humán genetikai állomány 20-féle aminosavat kódol, azonban szervezetünkben megtalálhatók további speciális aminosavak

is. A WHO szerinti javasolt fehérjebevitel 19 év feletti, átlagos aktivitású személyek számára 0,8 g/ttkg/nap. Ennél magasabb, átlagosan 1,2-2 g/ttkg napi fehérjebevitel hozzájárul az izommunka során keletkezett mikrosérülések javításához; izom hypertrophiájához; izmok, inak, ínszalagok, csontok terheléshez való adaptálásához; nitrogénegyensúly létrehozásához. Sporttáplálkozási szempontból a mennyiségi tényezőkön túl többek között célszerú figyelembe venni az időzítést is.

Ugyanis a testedzést követő két órán belül elfogyasztott magas biológiai értékú fehérje, valamint az elalvás előtti kazein is elősegíti az izomfehérje-szintézist. Különbséget kell tennünk sportáganként, ha fehérjebeviteli ajánlásról beszélünk. Állóképességi sportolóknak napi 1,2 - 1,4 g/ttkg javasolt; eró- és rezisztenciaedzést végző sportolóknál 1,6-1,7 g/ttkg szükséges. Zsírtömegből való fogyást nagy százalékkal rezisztencia típusú edzést végző, szigorú energiamegszorítás melletti kétszeres napi fehérjebeviteli mennyiség mellett tapasztaltak. kozás

Kulcsszavak: fehérje, funkció, szükséglet, sport, táplál-

\section{ABSTRACT}

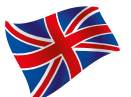

Proteins are macromolecules consisting of long chains of amino acid subunits. The human genom encodes 20 kinds of amino acids, at the same time our body contains additional specific amino acids. According to WHO the protein intake is $0.8 \mathrm{~g} / \mathrm{kg} /$ day for people with normal activity over 19 years of age.

Higher daily intake, avarage 1.2 to $2 \mathrm{~g} / \mathrm{kg} / \mathrm{d}$ of protein can promote to the improvement of micro-injury caused by muscle work, muscle hypertrophy, muscles-, tendoms-, ligaments and bones adaption to load, and produce nitrogen-balance. From sport nutrition viewpoint it is advised to consider intake timing beyond the quantitative factors. The high biological value of protein consumed within two hours after exercise and the presleep casein also promote muscle protein synthesis. We need to make differences between sport when we talk about protein input recommendation.

1.2 to $1.4 \mathrm{~g} / \mathrm{kg} / \mathrm{d}$ of proteins are recommended for stability athletes, additionally strenght and resistance training athletes need protein between 1.6 to $1.7 \mathrm{~g} / \mathrm{kg} / \mathrm{d}$. Weight loss by fat mass experienced high percentage of resistance-type training, with a doubling of daily protein intake at a tight energy level.

Key words: protein, function, recommendation, sport, nutrition

\section{A FEHÉRJÉK FELÉPÍTÉSE,}

\section{AMINOSAVPROFILJA}

A fehérjék mind a szervezetben, mind a táplálékban kiemelten összetett és változatos funkciójú tápanyagok a szénhidrátokhoz és zsírokhoz képest.

A fehérjék hosszú láncú aminosavakból felépülő makromolekulák. Szerves vegyületként szénből, hidrogénből, oxigénből és élelmiszerforrásonként eltéróen, átlagosan 16\% nitrogénből állnak. A fehérjemolekulákban az aminosavak peptidkötéssel kapcsolódnak egymáshoz, mely az aminosav amino- $\left(-\mathrm{NH}_{2}\right)$ és szomszédjának karboxilcsoportja (-COOH) között jön létre. Két aminosav összekapcsolódásából dipeptidek, hároméból tripeptidek, legfeljebb 10 aminosavból oligopeptidek és több száz aminosavból polipeptidek keletkeznek.

A fehérjék egyik jellemzője, hogy rendkívül változatos struktúrákat képesek létrehozni. Az aminosavlánc szekvenciája határozza meg a fehérjék primer szerkezetét, míg a szekunder szerkezet elsősorban a szabályos rendben kialakuló, a gerinc csoportok közötti hidrogénhíd kötések eredménye.

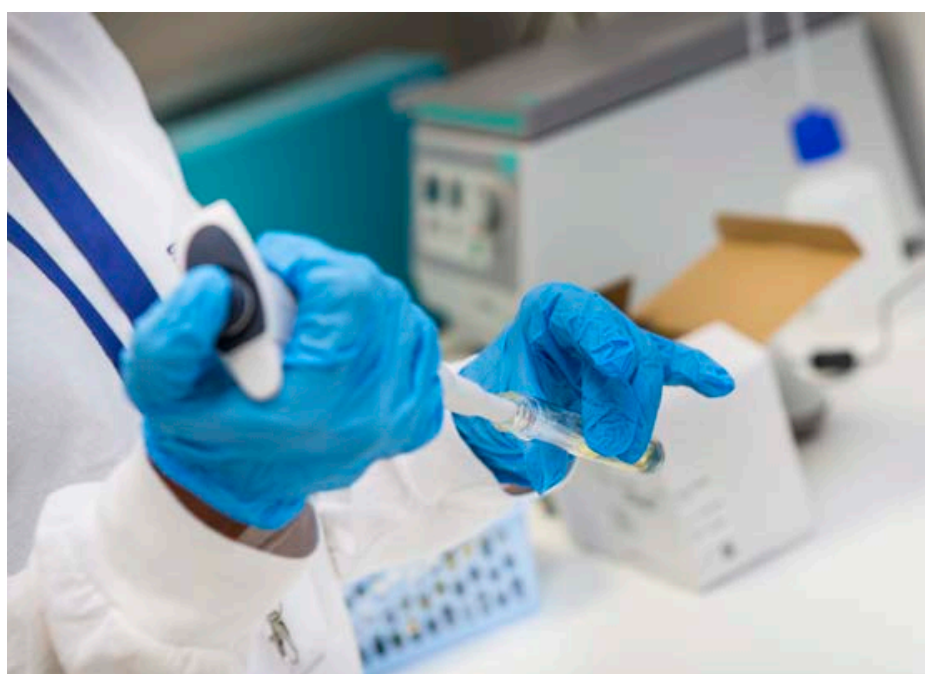




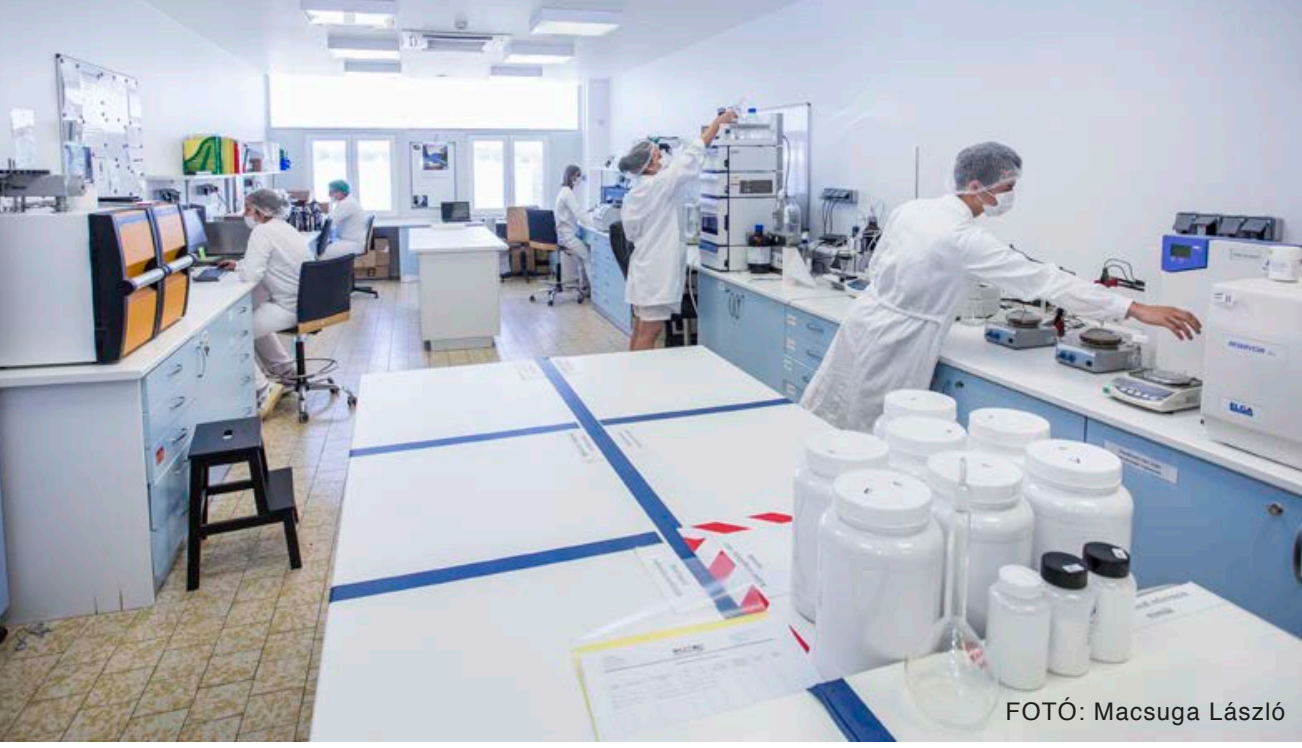

A tercier szerkezet a polipeptidlánc háromdimenziós, térbeli konformációja, a kvaterner szerkezet pedig azt mutatja, hogy a több alegységből álló fehérjék alegységei egymáshoz képest hogyan helyezkednek el a térben.

A fehérjék felépítésében 20-féle aminosav vesz részt, melyből kilencet a szervezet nem képes szintetizálni, így táplálékkal kell bevinni óket. Ezek az esszenciális aminosavak: izoleucin, leucin, lizin, metionin, fenil-alanin, treonin, triptofán, valin és gyermekkorban a hisztidin. Legjobb forrásai az állati eredetú termékek, mint pl. húsok, húskészítmények, halak, tej, tejtermékek, tojás, mivel ezek tartalmazzák az összes esszenciális aminosavat a megfelelő mennyiségben (komplett fehérjék). A gabonafélék, zöldségek, gyümölcsök, hüvelyesek, olajos magvak is tartalmaznak esszenciális aminosavat, csak egy vagy több aminosav mennyisége lényegesen kevesebb (limitáló aminosav). A hüvelyesek sok lizint és kevés metionint tartalmaznak, míg a gabonák ezzel ellentétesen több metionint és kevés lizint tartalmaznak. Ezek kombinációjával elérhető a megfelelő aminosavprofil.

A többi tizenegy aminosav: alanin, arginin, aszparagin, aszpartát, cisztein, glutamin, glutamát, glicin, prolin, szerin, tirozin.

\section{A FEHÉRJÉK EMÉSZTÉSE ÉS FELSZÍVÓDÁSA}

A fehérjék bontása a gyomor által szekretált pepszin, illetve a hasnyálmirigynedvből származó tripszin, kimotripszin és elasztáz segítségével történik. Az emésztés szabad aminosavakat (kb. 75\%) és di-, illetve tripeptideket eredményez. Az enterocyták lumináris membránján csak ezen méretû molekulák képesek átjutni, mely aktív transzport segítségével történik. A kefeszegélyekben öt különböző specifitású $\mathrm{Na}^{+}$-aminosav kotranszportert írtak le. Ezek csoportspecifikusak, mindegyikük több aminosav szállítását végzi.

A táplálkozásból, illetve a szervezet saját fehérjéinek lebontásából származó aminosavak egy közös készletet képeznek.

\section{A FEHÉRJÉK \\ SZERVEZETBEN BETÖLTÖTT SZEREPE}

A képződő fehérjék fajspecifikusak, aminosav-összetételük állandó, aminosav-szekvenciájukat a genom struktúrgénjei kódolják. Táplálkozás-élettani szempontból fontos, hogy az esszenciális aminosavak bevitelére kiemelt figyelmet fordítsunk, hiszen a nem esszenciális aminosavak felépüléséhez is szükségesek. A fehérjék amellett, hogy energiát szolgáltatnak, élettani szempontból számos funkciót látnak el. Többek között a sejtek egyik legfontosabb strukturális alkotói. Közremúködik a vázizomzat (körülbelül 25\%-a fehérje), a bőr a csontozat szerves állományának, valamint a kötőszövet (kollagén, elasztin) kialakításában. Enzimeket szintetizál belőlük, amelyek részt vesznek az anyagcsere-folyamatokban (emésztőenzimek), motorikus funkciókban (aktin, miozin), légzésben (haemoglobin), illetve a transzportfolyamatokban. Speciális funkciójú fehérjék közé sorolhatók a peptidhormonok, mint például az inzulin, glukagon, növekedési hormonok (azon belül is az érrendszer eredetú VEGF, vérlemezke eredetű PDGF, inzulinszerú IGF, valamint az agyi erdetű BDNF. Az immunrendszer múködésében részt vevő immunglobulinok szintén fehérje természetű elemek, melyet a plazmasejtek termelnek. A májban szintetizáló albumin a szervezet egyetlen mozgó fehérjeraktára.

\section{AJÁNLOTT BEVITELI MENNYISÉGEK}

A mai táplálkozási ajánlás (RDA) szerint 19 év felett napi $0,8 \mathrm{~g} / \mathrm{ttkg}$ fehérje bevitele javasolt. Sportolóknál ez a mennyiség magasabb, átlagosan 1,2-2 g/ttkg/nap közötti, az alábbi szükségletek kielégítéséhez (Phillips, 2012):

- az izommunka során keletkezett mikrosérülések javításához és a sejtek remodellingjéhez;

- az izmok, csontok, inak és ínszalagok terheléshez való adaptálásához, hogy jobban ellenálljanak a mechanikus hatásoknak;

- az izom hypertrophiájához;

- az immunrendszer optimális múködéséhez;

- az optimális élettani funkciókat ellátó összes plazmafehérje megfelelő termelődéséhez

- a nitrogénegyensúly létrehozásához.
A fehérjeigényt befolyásolja az egyén életkora, testösszetétele, sportága, edzésintenzitása, a felkészülés státusza, illetve hogy mióta űzi az adott sportágat. Katabolizmussal járó állapotokban (pl.: szigorú kalóriamegszorításkor vagy sérülés miatti inaktivitáskor) a fehérjebevitel napi $2 \mathrm{~g} / \mathrm{ttkg}$ fölé is emelkedhet a zsírmentes testtömeg megtartása érdekében (Phillips - Van Loon, 2011). Egy étkezéssel bevitt nagy mennyiségú ( $40 \mathrm{~g}$ feletti) fehérjének Moore és társai (2009) szerint nincs bizonyítottan nagyobb hatása az izomfehérje-szintézisre, mint 20-40 g fehérje elfogyasztásának, tehát a bevitt fehérje mennyiségének növelése nem egyenesen arányosan okoz nagyobb izomfehérje-szintézist. Egyszerre $40 \mathrm{~g}$ feletti fehérje bevitele csupán testsúlycsökkentéskor, izomtömeg-megtartás céljából javasolt.

\section{A FEHÉRJÉK BEVITELÉNEK IDŐZÍTÉSE}

A fehérjék mennyiségén túl fontos tényező azok bevitelének időzítése is. A testedzést követő két órán belüli 0,25 g/ttkg (vagy egy étkezéssel bevitt 20-40 g) magas biológiai értékű fehérje fogyasztása elősegíti az izomfehérje-szintézist (Phillips, 2014). Mivel a rezisztencia jellegú edzés szervezetre gyakorolt anabolikus hatása sokáig fennáll, a vázizmok 24 órán keresztül igénylik a fehérje- és aminosav-utánpótlást, ezért 3-5 óránként ajánlott megismételni a magas fehérjetartalmú étkezéseket (Tripton et al. 2003).

A testedzés utáni időszakon kívül kiemelt szerepe van az alvás előtt fogyasztott fehérjének is, ugyanis 30-40 g kazein növeli az éjszakai izomfehérje-szintézist (Res et al. 2012).

\section{SPORTÁGSPECIFIKUS AJÁNLÁSOK}

A szükséges fehérje mennyisége sportáganként eltérő. Állóképességi sportolóknak napi 1,2-1,4 g/ttkg fehérje bevitele javasolt (Phillips - Moore - Tang, 2007). D'lugos és mtsai (2016) szerint állóképességi sportágakban nincs a teljesítményre jobb hatással, ha edzés előtt és közben fehérjét és szénhidrátot egyaránt adunk a sportolónak, mintha csak szénhidrátot fogyasztana. A fehérjék teljesítményfokozó hatása ugyan nem igazolt állóképességi sportágakban, más szempontból azonban Saunders és mtsai (2004) mégiscsak hasznosnak találták a fehérjebevitelt ezen sportágakban is. Az állóképességi edzés közben és után fogyasztott fehérje- és szénhidráttartalmú italok, gélek fogyasztása elnyomja az izomroncsolódás egyik markerét (kreatinkináz) és csökkenti az izomfájdalmakat, így tehát óránként $0,25 \mathrm{~g} / \mathrm{ttkg}$ fehérjével ajánlott kiegészíteni a testedzés közben elfogyasztott szénhidrát mennyiségét.

Erő- és rezisztenciaedzést végző sportolóknál a fellépő katabolizmus idejének rövidítése és az anabolizmus elősegítése a cél, melyhez napi 1,6-1,7 g/ttkg fehérje fogyasztása szükséges (Phillips - Moore - Tang, 2007). Az anabolizmus legfontosabb feltétele a magas szabad aminosav koncentráció a vérben, különösen az egy étkezésre bevitt 20-40 g fehérjé- 
ből a 10-12 g esszenciális aminosav és 1-3 $g$ leucin (Jäger et al., 2017). További feltétel még az inzulin jelenléte (Abdulla et al, 2016).

A megemelt fehérjebevitelnek jelentôs hatása van a testösszetétel-változtatásban is. Pasiakos és mtsai megállapították (2013), hogy szigorú energiamegszorítás mellett a vizsgált személyek közül azok veszítettek legnagyobb mértékben a testtömegükből, akik az RDA szerinti ajánlott mennyiségú fehérjét vitték be, ugyanakkor szintén ezen csoport tagjai veszítettek a legtöbbet a sovány testtömegükből és a legkevesebbet zsírból (48\%), ami nem előnyös sportolás szempontjából. Az RDA kétszeresét (1,6 g/ttkg) és az RDA háromszorosát $(2,4 \mathrm{~g} /$ ttkg) fogyasztó csoportoknál szintén jelentős testtömegcsökkenés volt tapasztalható, azonban ez 70\%, illetve 64\%-ban zsírból történt. Jäger és mtsai kutatásai szerint (2017) rezisztencia jellegú edzés alacsony kalóriatartalmú (30-40 E\%-kal csökkentett) étrenddel és magas (2-3x-os RDA) fehérjebevitellel kombinálva nagyobb arányú testzsírszázalék-vesztést és sovány testtömeg megtartást eredményez, mint alacsonyabb fehérjebevitel esetén. A kutatásából az is kiderül, hogy a rezisztenciaedzés magas (2-3x-os RDA) fehérjebevitellel kombinálva energiabőségben izomkeresztmetszet-növekedést okoz, és növeli a sovány testtömeget.

Összességében elmondható, hogy fehérjék számos élettani folyamatban fontos szerepet töltenek be. Rendszeres fizikai terhelés esetén különösen nagy jelentősége van a bevitt fehérjék mennyiségének, minőségének és időzítésének.

\section{IRODALOMJEGYZÉK}

Abdulla H., Smith K., Atherton P.J., Idris I. (2016): Role of insulin in the regulation of human skeletal muscle protein synthesis and breakdown: a systematic review and meta-analysis. Diabetologia. 59. 1. 44-55. DOI: 10.1007/ s00125-015-3751-0

D'lugos A.C., Luden N.D., Faller J.M., Akers J.D (2016): Supplemental protein during heavy cycling training and recovery impacts skeletal muscle and heart rate responses but not performance. Nutrients. 8. 9. 550 DOI: $10.3390 /$ nu8090550

Fonyó, A. (2011): Az orvosi élettan tankönyve. Medicina Könyvkiadó Zrt., Budapest

Institute of Medicine, Food and Nutrition Board. (2005): Dietary Reference intakes for Energy, Carbohydrate, Fiber, Fat, Fatty Acids, Cholesterol, Protein, and Amino Acids. The National Academies Press, Washington, DC

Jäger, R., Kerksick, C. M., Campbell, B. I., Cribb, P. J (2017): International Society of Sports Nutrition Position Stand: protein and exercise. Journal of the International Society of Sports Nutrition. 14. 20. DOI:10.1186/s12970017-0177-8

Moore D.R., Robinson M.J., Fry J.L., Tang J.E. (2009): Ingested protein dose response of muscle and albumin protein synthesis after resistance exercise in young men. The American Journal of Clinical Nutrition. 89. 1. 161-168. DOI: 10.3945/ajen.2008.26401

National Academies Press (US); 1989. Recommended Dietary Allowances: 10th Edition. From: https://www.ncbi. nlm.nih.gov/books/NBK234932/ DOI: 10.17226/1349

Nyitray, L. - Pál, G. (2013): A biokémia és molekuláris biológia alapjai. In: Pál, G. (szerk.): Aminosavak, peptidkötés, a fehérjék elsődleges és másodlagos szerkezete. ELTE TTK, Budapest, 97-132. o

Pasiakos S.M., Cao J.J., Margolis L.M., Sauter E.R. (2013): Effects of high-protein diets on fat-free mass and muscle protein synthesis following weight loss: randomized controlled trial. Federation of American Societies for Experimental Biology Journal. 27. 9. 38373847 . DOI: 10.1096/fj.13-230227
Phillips S.M., Moore D.R., Tang J.E. (2007): A critical examination of dietary protein requirements, benefits, and excesses in athletes. International Journal of Sport Nutrition and Exercise Metabolism. 17. 1. 58-76. DOI: 10.1123/ijsnem.17.s1.s58

Phillips S.M., Van Loon L.J. (2011): Dietary protein for athletes: from requirements to optimum adaptation. Journal of Sports Science. 29. 1. 29-38. DOI: 10.1080/02640414.2011.619204.

Phillips, S.M. (2012): Dietary protein requirements and adaptive advantages in athletes. British Journal of Nutrition. 108. 2. 158-167. DOI: 10.1017/ S0007114512002516.

Phillips, S.M. (2014): A brief review of higher dietary protein diets in weight loss: a focus on athletes. Sports Medicine. 44. 2. 149-153. DOI: 10.1007/s40279-0140254-y

Res P.T., Groen B., Pennings B., Beelen M. (2012): Protein ingestion before sleep improves postexercise overnight recovery. Medicine \& Science in Sports \& Exercise. 44. 8. 1560-1569. DOI: 10.1249/ MSS.0b013e31824cc363

Saunders M.J., Kane M.D., Todd M.K. (2004): Effects of a carbohydrate-protein beverage on cycling endurance and muscle damage. Medicine \& Science in Sports \& Exercise. 36. 7. 1233-1238. DOI: 10.1249/01. MSS.0000132377.66177.9F

Tipton K.D., Borsheim E., Wolf S.E., Sanford A.P. (2003): Acute response of net muscle protein balance reflects $24-\mathrm{h}$ balance after exercise and amino acid ingestion. American Journal of Physiology Endocrinology and Metabolism. 284. 1. 76-78. DOI: 10.1152/ajpendo.00234.2002

Tőzsér, J. - Emri, T. - Csősz, É. (2011): Fehérjebiotechnológia. Debreceni Egyetem, Debrecen. From: http://www.tankonyvtar.hu/hu/tartalom/ tamop425/0011 1A Proteinbiotech hu book/ch01.html

Wunderlich, L. - Szarka A. (2014): A biokémia alapjai. Typotex Kiadó, Budapest

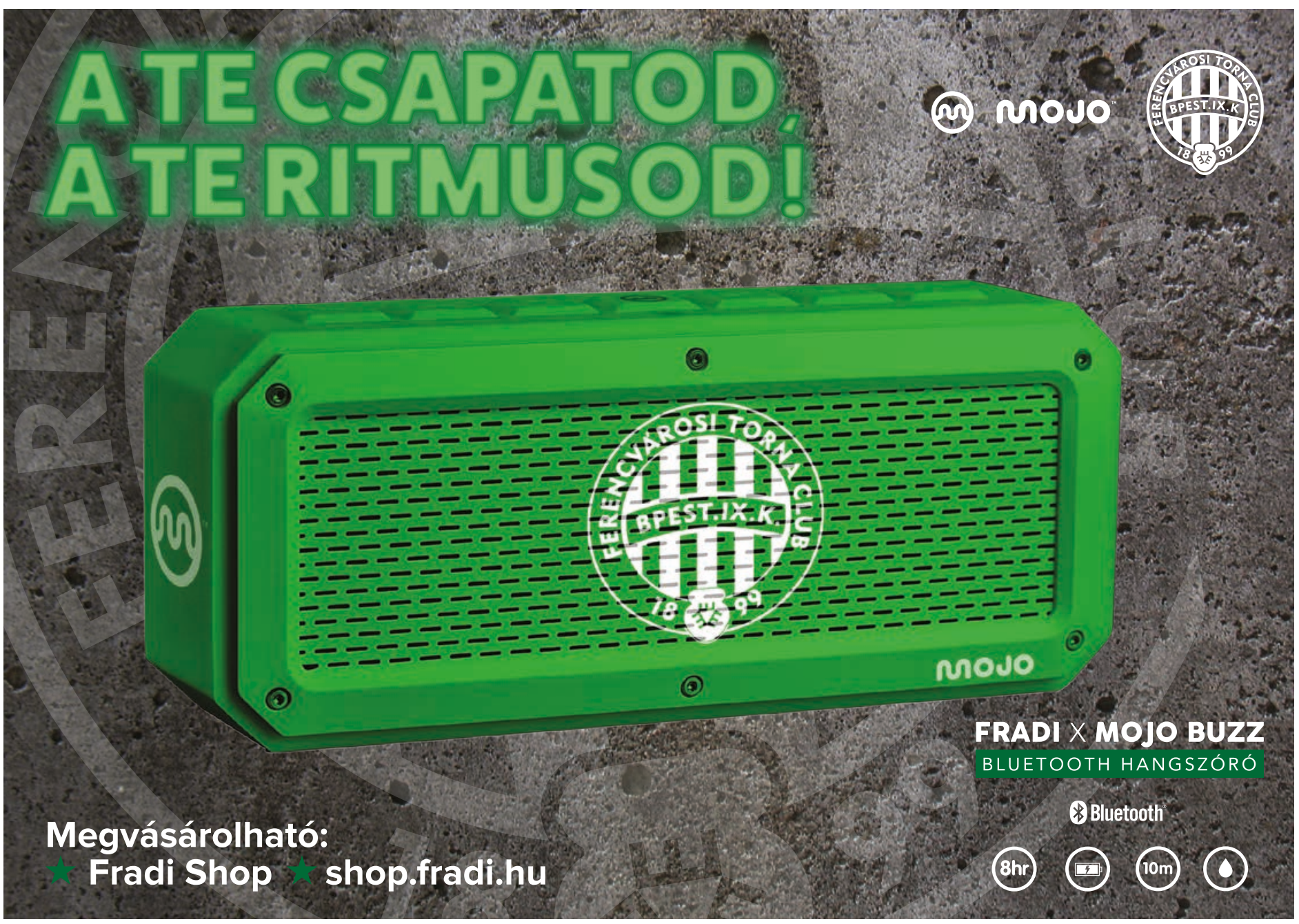

